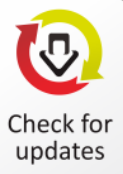

updates

Article Type: Research Paper

\title{
Ownership Concentration, Firm Size, and Information Value Relevance: Indonesian Evidence
}

\author{
Krismiaji $^{1 *}$, Dwi Haryono Wiratno ${ }^{1}$, Sidiq Ashari ${ }^{1}$
}

\begin{abstract}
This paper describes empirical evidence investigated the effect of ownership concentration and firm's size on the accounting information value relevance. Ownership concentration $(\mathrm{OC})$ is measured by Herfindahl index; the firm's size is measured by a log of total assets, whereas value relevance is measured by the Ohlson' Price Model. Using a sample of 119 manufacturing firms listed in Indonesian Stock Exchange (IDX) for the year of 2011-2015, this research finds that ownership concentration positively affects both the value relevance of earnings per share and book value per share. Moreover, the firm's size negatively affects the value relevance of earnings per share and book value per share. This study contributes to the existing literature about value relevance of ownership concentration and value relevance of firm's size, especially in the post- IFRS adoption period.
\end{abstract}

${ }^{1}$ Accounting Academy of YKPN Yogyakarta, Daerah Istimewa

Yogyakarta, Indonesia.

*CORRESPONDENCE:

xmiaji@gmail.com

THIS ARTICLE IS AVAILABLE IN:

http://journal.umy.ac.id/index.php/ai

DOI: 10.18196/jai.2002119

KEYWORDS: value relevance; ownership concentration; firm's size

\section{CITATION:}

Krismiaji, Wiratno, D. H., \& Ashari, S. (2019). Ownership Concentration, Firm Size, and Information Value Relevance: Indonesian Evidence. Journal of Accounting and Investment, 20(2), 99-113.

\section{ARTICLE HISTORY}

Received:

30 September 2018

Reviewed:

24 October 2018

Revised:

26 October 2018

Accepted:

24 November 2018

\section{Introduction}

This paper describes the result of empirical research which investigates the impact of ownership concentration and firm size on accounting information value relevance of two accounting variables, given by manufacturing firms listed in Indonesia Stock Exchange (IDX) for the year of 2011 to 2015 . This research motivated by the fact that the information content of accounting numbers in ascertaining security prices/returns is one of the most fundamental issues in finance and accounting. Although many studies about information content and value relevance of accounting information had been done, the introduction of some concepts in recent years, including corporate governance and the newest accepted accounting standard which is International Financial Accounting Standard (IFRS), affect the accounting information quality (Krismiaji, Aryani, \& Suhardjanto, 2016). The implementation of IFRS, as one of the high-quality accounting standards, leads to the cross-country investment (Krismiaji, 2013). 
Krismiaji, Wiratno \& Ashari

Ownership Concentration, Firm Size, and Information Value Relevance

Furthermore, the changes in the structure of share ownership because more foreign investors purchase shares from domestic stockholders. The easier of investors from the whole parts of the world invest in other countries, the growth of capitalization and thus the size of the firm would be faster. Therefore, it opens a new opportunity to investigate further in the issue of accounting value relevance, especially in connection to ownership concentration, which is one of the corporate governance components, and firm size.

The first study investigated information content is performed by Ball and Brown (1968) who report that unexpected earnings are significantly related to abnormal stock returns. Since, then many researchers have examined the information content of accounting information in various markets (e.g., Pathirawasam, 2010; Chen \& Huang, 2014). Such research generally had overlooked mainly to the notion that ownership may be related to the value-relevance of accounting information, despite the fact of the agency theory, ownership structure may affect the quality of accounting information (Jensen \& Meckling, 1976). This study also opens a new opportunity to investigate further in the accounting information value relevance which includes firm ownership variable, since the relationship of firm's ownership to the value-relevance of accounting information is a limited (if any) empirical issue. Therefore, the association between ownership concentration as a mechanism to influence managers, and value relevance of accounting information is needed to investigate more deeply.

Value relevance is a field of research that investigates how various factors interact with company value or financial measures (Nilsson \& Strand, 2015). We argue that accounting information of large firms is of higher quality than that of small firms. Therefore, the value relevance of accounting information of large firms may higher than that of small firms. Previous reports mixed results. Yokoyama, Baioco, Sobrinho, and Neto (2015) report that large size companies present a more value relevant information than the smaller size companies, whereas Nilsson and Strand (2015) and Jalalian, Barzegari, and Mohammadi (2016) find that firm's size does not affect the value relevance of information. Additionally, Bae and Jeong (2007) find that the value-relevance of earnings and book value is significantly smaller for firms affiliated with business groups, whereas Brimble and Hodgson (2007) find that the value relevance of core accounting earnings has declined for small stocks.

This research aims to complement previous literature about value relevance by conducting research which investigates the effect of concentrated ownership and the firm's size on the value relevance of accounting information in an emerging market which is Indonesia. Therefore, we formulate our research question as follow: do concentrated ownership and the firm's size affect the value relevance of accounting information produced by Indonesian manufacturing publicly-held firms?

The contribution of this is fourfold. First, it provides the conceptual foundations for how concentrated ownership impacts the value-relevance of accounting information, and ultimately how concentrated ownership impacts financial value. Second, the empirical work in this paper adds to the vast body of knowledge within value-relevance research 
Krismiaji, Wiratno \& Ashari

Ownership Concentration, Firm Size, and Information Value Relevance

and concentrated ownership research. Third, this study provides new evidence about the value relevance of accounting information by involving an element of corporate governance which is concentrated on the ownership. Fourth, this research also presents an additional result of analyzing the firm's size in association with the value relevance of accounting information.

\section{Literature Review and Hypotheses Development}

This research based on the agency theory which predicts and explains the behavior of related parties in principal-agent relationships (Jensen \& Meckling, 1976). In this relationship, both principal and agent are assumed to be self-interested and act for their interests. Therefore, when principal delegates the authority to the agent, the agent tends to pursue personal agendas such as empire building and wasting of the substantial resources for personal benefits rather than fulfilling the principal interest (Barnea, Haugen, \& Senbet, 1985). Accordingly, principal-agent relationships create a potential conflict between the principal and the agent.

The agency problem occurred when a company listed on the stock exchange and there are some shareholder groups. The groups have an incentive and ability to control and monitor both decisions and actions of the agent (management). The agency problems increase when the company's growth is low, but it has high free cash flows. It proposes that concentrated ownership may impact the value-relevance. While it suggests that the traditional owner-manager agency conflict, the first type of agency problem, is mitigated in publically listed concentrated-owned firms, there are also potential downsides of family ownership (Anderson, Mansi, \& Reeb, 2003; Demsetz \& Lehn, 1985; Villalonga \& Amit, 2006). The concentration of ownership and management in these firms may lead to Type II agency problems.

Furthermore, concentrated ownership is related to the level of unidentifiable intangible assets in firms, as the owners place a different importance weight upon non-financial goals and consequently increasing social capital and human capital (Hasso \& Duncan, 2013; Miller, Le Breton-Miller, Scholnick, \& Montreal, 2008; Sirmon \& Hitt, 2003). In summary, it suggests that concentrated ownership is related to the value-relevance of accounting information through its relationship to the qualitative characteristics of accounting information (Hasso, 2013). These qualitative characteristics are accounting information quality (faithful representation) and unidentifiable intangible assets (relevance).

Value relevance is the ability of the accounting numbers disclose in the financial statement to explain the market price of shares (Tariverdi, Sedighikamal, \& Naderi, 2016). Some scholars Harris and Ohlson (1990), Francis and Schipper (1999), have given their interpretation of the term value relevance. The variable is value relevant if it enables the prediction of the stock price by capturing the intrinsic value of the stock (Harris \& Ohlson, 1990). Value relevance research investigates the association between a security price as a dependent variable and a set of independent accounting variables 
Krismiaji, Wiratno \& Ashari

Ownership Concentration, Firm Size, and Information Value Relevance

(Beaver, 2002). Holthausen and Watts (2001) reviewed the value relevance of information and its effects on the standard setting. Based on accounting theories, the value relevance of accounting variables and equity valuation has limited implications for the standard setters. Healy and Palepu (2001) investigated optional information disclosure by managers. They also showed that earnings, book values, and other required information have informational content. The theoretical foundation of valuerelevance studies is a combination of a valuation theory plus contextual accounting arguments that allow researchers to predict how accounting variables relate to the market value of equity (Beaver, 2002).

\section{Value Relevance and Concentrated Ownership}

Ownership concentration has a significant impact on the demand and supply of corporate disclosure (Zhang, 2012). Two arguments relating to the effects of ownership are a concentration entrenchment effect and an alignment effect. The entrenchment effect refers to the argument that controlling shareholders determine how profits distributed among shareholders, and the interests of minority shareholders may expropriate by the controlling shareholders (Fama \& Jensen, 1983; Shleifer \& Vishny, 1997). In contrast, the alignment effect based on the argument that the controlling of shareholders are willing to build a reputation for not expropriating minority shareholders (Gomes, 2000). The effect of ownership concentration on corporate disclosure is the combination of entrenchment and alignment effects. This may cause the non-linear relationship between ownership concentration and the level and quality of corporate disclosure. The traditional agency problem deals with the conflict between management and shareholders. However, Gomes (2000) argues that in the legal system that does not protect minority shareholders, agency problem may also arise between controlling shareholders and minority shareholders. As a result, at different levels of ownership concentration, the conflicts of interest may shift from those between management and shareholders to those between the majority shareholders and minority shareholders. At the low level of ownership concentration, both the entrenchment effect and an alignment effect are weak. External shareowners, in this situation, do not influence corporate disclosure decision makings and therefore the company has no pressure to disclose additional information. As the ownership concentration level increases, primarily when a company's shares owned by a few controlling shareholders as well as a large number of minority shareholders, the level and the quality of corporate disclosure improves as a result of the increased power of external shareholders and alignment effect.

Agency theory explains the relationship between owners and managers. One of the accepted assumptions is that owners desire to maximize wealth and at the same time managers may have other interests such as high compensation, low effort levels, expense preference, empire buildings, and so on. Thomsen and Pedersen (2000) report that top managers are assumed to have a personal interest in diversification at the corporate level because of risk aversion, expense preference, and empire building. Concentrated ownership might counteract corporate diversification and increase shareholder value. Therefore, ownership concentration is one of the pre-requisites to 
Krismiaji, Wiratno \& Ashari

Ownership Concentration, Firm Size, and Information Value Relevance

influence managers' activities. Meanwhile, Zeckhauser and Pound (1990) find that the price-to-earnings ratio and ownership concentration has a positive relationship. Additionally, Thomsen and Pedersen (2000) find that after controlling for other variables, ownership concentration has a positive relationship with the market-to-book value of equity and return on asset. Additionally, Leng (2004) finds that the proportion of shares held by institutional investors significantly influenced on return on equity in Malaysian listed companies. Finally, Bae and Jeong (2007) examine the quality of earnings and book value provided by firms with ownership concentrated and they find that ownership concentrated firms tend to provide less value-relevant earnings and book value. Based on the review of previous research, this research hypothesizes that concentrated ownership affects the information disclosed by a firm. Therefore, the hypothesis can be stated as follow:

$\boldsymbol{H}_{1}$ : Concentrated ownership positively affects the value relevance of accounting information.

\section{Value Relevance and The Firm's Size}

Prior studies indicate that the firm size is a critical factor which determines the value relevance of accounting information (Bae \& Jeong, 2007; Brimble \& Hodgson, 2007). Brimble and Hodgson (2007) point out that the value relevance of large firms is higher than that of small firms. They examine the value relevance of earnings and book value information in Australian Stock Exchange from 1974 to 2001, and they find the lowvalue relevance of earnings, book value and combine variables. Further, they report that explanatory power for small firms is much higher when compared to large firms. Hodgson and Clarke (2000) examine the value relevance of earnings and cash flows for companies listed in Australian Stock Exchange, and they find that explanatory power and earnings response coefficients are more pronounced for large firms than small firms. Further, Bae and Jeong (2007) find that the value relevance of accounting information to the stock price is significantly smaller for Chaebol- affiliated firms and below average for the whole sample. They also find that the larger of the firm has a higher power in explanatory.

Chen and Zhang (2007) examine the cross-sectional relationship between firm accounting variables and stock returns. They find that all identified factors are highly significant and there is no visible indication of an increasing or decreasing trend for the adjusted $R^{2}$ as size increase. Yokoyama, Baioco, Sobrinho, and Neto (2015) report that large size companies present a more value relevant information than the smaller size companies, whereas Nilsson and Strand (2015) and Jalalian, Barzegari, and Mohammadi (2016) find that firm's size does not affect the value relevance of information. Based on the review of previous research, this research hypothesizes that the firm's size affects the information disclosed by a firm. Therefore, the hypothesis is stated as follow:

$\boldsymbol{H}_{2}$ : Firm size positively affects the value relevance of accounting information. 


\section{Research Method}

\section{Sample Selection}

The sample used in this research is firms listed on the Indonesian Stock Exchange (IDX). The sample was selected using the purposive sampling technique. The first requirement is that it is a public company listed at the IDX from 2011 to 2015. The second is that these firms have publicly available information. The third requirement is that the firms are manufacturing company. The data came from three sources, the Indonesian Capital Market Directory (ICMD), www.idx.co.id, and the company's website. The unit analysis used is firm-year.

\section{Variable Definition and Measurement}

\section{Value Relevance}

There are two models commonly used to assess value relevance, the price model, and the returns model. The price model is used to test the relationship between stock price and book value (Ohlson, 1995). This model offers a model which connects market value with earnings and book value. In this model, current earnings serve as a proxy for abnormal earnings, while book value is a proxy for the present value of expected future normal earnings. Ohlson's model expresses a firm's market value (stock price) as a linear function of earnings, book values, and other value-relevant information. The model has many requirements and provides a useful benchmark for conceptualizing how market value relates to accounting data and other price-relevant information. The statistical association between stock price and earnings and book value used as the main metric for measuring relevance value of accounting number. If accounting variables have value relevance for investors, then there will be an association between stock price and earnings and book value. Additionally, earnings and book value coefficient will statistically be significant. This association measured by the explanatory power $\left(R^{2}\right)$ of the regression model. The model is specified as follows:

$$
P_{i t}=\alpha_{i t}+\beta_{1} E P S_{i t}+\beta_{2} B V S_{i t}+\varepsilon_{i t}
$$

where:

$\mathrm{P}_{\text {it }} \quad=$ stock price firm $\mathrm{i}$ at time $\mathrm{t}$, three months after the fiscal year-end at time $\mathrm{t}$

EPS $_{\text {it }} \quad=$ earnings per share of firm $\mathrm{i}$ at time $\mathrm{t}$

BVS $_{\text {it }}=$ the book value per share of firm $\mathrm{i}$ at time $\mathrm{t}$

$\varepsilon_{\text {it }} \quad=$ error term

\section{Concentrated Ownership (OWN)}

The Herfindahl index of large shareholders measures concentrated ownership for five years. The Indonesian Companies Act of 1995 requires firms to disclose directors' report and ownership data in their annual reports. Hence, ownership data are readily available from the sections on the analysis of shareholdings and director's reports of firms' 
Krismiaji, Wiratno \& Ashari

Ownership Concentration, Firm Size, and Information Value Relevance

annual reports. The value of the $\mathrm{H}$ is the sum of the squares of the ownership of the shares of each kind of ownership, and the value is between 0 and 1. It calculated as follows:

$$
H=\sum_{i=1}^{n}(\text { Share Ownership Portion })^{2}
$$

Where $\mathrm{i}$ refers to an individual firm and $\mathrm{n}$ refers to the number of firms. The higher the index, the more concentrated the ownership. Higher ownership concentration leads to the decrease of information disclosure and the increase of agency problem (Leuz, Nanda, \& Wysocki, 2003).

Firm's Size (SIZE)

Log natural assets measure Firm's size as an independent variable. Firm size is a wellestablished determinant for the firm's value and affects many aspects of a firm's operation. Ronen and Yaari (2002) and Zhou and Lobo (2006) note that large firms may have more opportunities to overstate earnings because of the complexity of their operations and the difficulty for interested parties to detect overstatement.

\section{Control Variables}

The control variables that we select are standard for the literature that examines the link between concentrated ownership and the firm's size with value relevance of accounting information. Previous research found that value relevance of earnings and book value might also be affected by several factors including earnings sign (Collins, Maydew, \& Weiss, 1997; Barth, Beaver, \& Landsman 1998; Collins, Pincus, \& Xie, 1999), profitability (Krismiaji \& Hermala, 2018), and leverage (Alfraih, Alanezi, \& Alanzi, 2015). Therefore, we include earnings sign (Loss), profitability (ROA) and leverage (LEV) as control variables in assessing the association between concentration ownership and firm's size with value relevance. Lev or leverage is a control variable used to control variations of a firm's capital structure. Larcker and Richardson (2004) argue that the presence of debt-holders offers additional monitoring benefit via external capital providers who have an incentive and the ability to monitor firm activities to protect investments. Therefore we use leverage to capture the effect of the debt ratio. This variable is measured by dividing total liabilities with total assets. The low leverage indicates that a company has a low cost of capital (Kim \& Shi, 2012; Li, 2010) because of the higher the leverage, the higher of the return required by investors. Company's profitability is proxy by return on assets (ROA). ROA is measured and calculated by dividing net profit before taxes with total assets. Earnings sign (LOSS) is the last control variable. Previous research found that value relevance of earnings and book value might be affected by several factors, including earnings sign (Collins, Maydew, \& Weiss, 1997; Barth, Beaver, \& Landsman 1998; Collins, Pincus, \& Xie, 1999). The loss is a dummy variable that equals one if the firm achieves negative earnings and 0 otherwise. 


\section{Model Specification}

To test the hypotheses, model (1) is extended by involving variables of concentrated ownership, firm's size, and control variables, and thus the models are as follows:

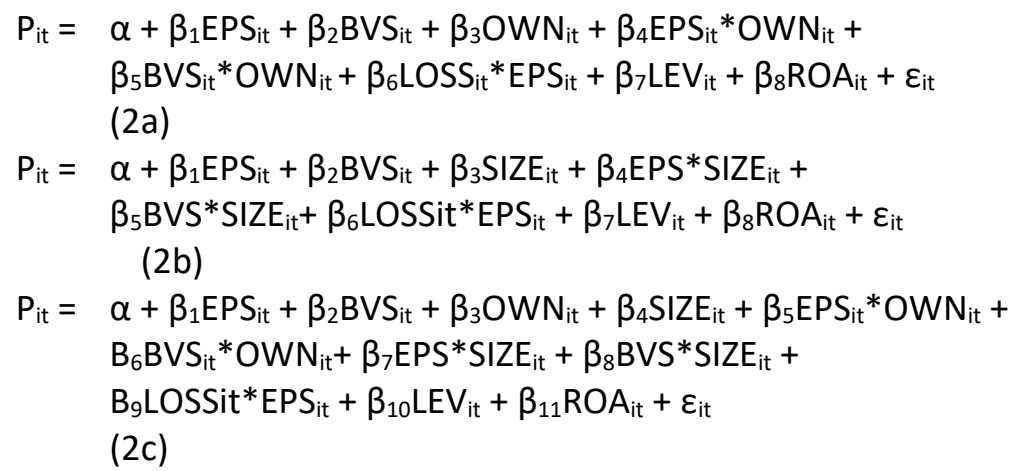

Where:

$\mathrm{P}_{\mathrm{it}} \quad=$ stock price per share for firm $i$ at time $t$, three months after the fiscal year-end of time $t$

EPS $_{\text {it }} \quad=$ earnings per share of firm $i$ at time $t$

BVS $_{\text {it }} \quad=$ the book value per share of firm $i$ at time $t$

$\mathrm{OWN}_{\text {it }}=$ concentrated ownership of firm $i$ at time $t$

$\mathrm{SIZE}_{\text {it }} \quad=$ firm's size of firm $i$ at time $t$

LOSS $_{\text {it }}=$ dummy variable that equals 1 if the firm achieves negative earnings and 0 otherwise

$\mathrm{LEV}_{\text {it }} \quad=$ total liabilities divided by total assets of firm $i$ at time $t$

$\varepsilon_{\text {it }} \quad=$ error term

Hypotheses $1(\mathrm{H} 1)$ is accepted or confirmed by empirical data if the estimated coefficient for $\beta_{4} \mathrm{EPS}_{i t}{ }^{*} O W N_{i t}$ and $\beta_{5} B V S_{i t}{ }^{*} O W N_{i t}$ in equation (2a) is positive and significant, whereas hypothesis $2(\mathrm{H} 2)$ is accepted or confirmed by empirical data if the estimated coefficient for $\beta_{4} \mathrm{EPS}_{\mathrm{it}}{ }^{*} \mathrm{SIZE}_{i t}$ and $\beta_{5} \mathrm{BVS}_{i \mathrm{it}}{ }^{*} \mathrm{SIZE}_{i t}$ in equation (2b) is positive and significant.

\section{Result and Discussion}

Based on the sampling process described, this study used 119 firms in the period between 2011 and 2015 as the data sample. The total observations consist of 595 firmyears.

\section{Univariate analysis}

Table 1 presents descriptive statistics for the sample data. The result shows that all variables used in this research have logic variation. Table 1 reports that mean (Std. Dev.) of stock price per share from 2011 to 2015 is 4023.89 (10109.76). Earnings per share 
(EPS) has mean value (Std. Dev.) value of 575.50 (3389.82), and book value per share (BVS) has mean value (Std. Dev.) value of 2423.34 (5984.64). This table shows that OC and SIZE have the mean value of 0.54 and 6.21 respectively with a standard deviation of 0.16 and 0.74 .

Table 1 Descriptive Statistic

\begin{tabular}{lrrrr}
\hline & Minimum & \multicolumn{1}{c}{ Maximum } & \multicolumn{1}{c}{ Mean } & \multicolumn{1}{c}{ Std. Deviation } \\
\hline Pit & 0.00 & 98400.00 & 4023.89 & 10109.76 \\
EPS & -7061.00 & 55576.08 & 575.50 & 3389.82 \\
BVS & -12182.44 & 53057.63 & 2423.34 & 5984.64 \\
OC & 0.26 & 0.98 & 0.54 & 0.16 \\
SIZE & 1.70 & 8.39 & 6.21 & 0.74 \\
EPSOC & -5700.54 & 40389.01 & 350.99 & 2342.98 \\
BVSOC & -11777.63 & 34061.39 & 1356.16 & 3665.86 \\
EPSZ & -38799.32 & 347402.95 & 3637.16 & 21003.38 \\
BVSZ & -74552.75 & 319212.32 & 15175.96 & 37095.63 \\
LEPS & -17350.39 & 727.96 & -90.42 & 901.81 \\
ROA & -0.76 & 3.21 & 0.06 & 0.19 \\
LEV & 0.00 & 248584.02 & 697.09 & 11710.91 \\
\hline
\end{tabular}

\section{Bivariate Analysis}

To test the research hypotheses, we use ordinary least square (OLS) regression. All classical assumptions test for these techniques have been done. The result proves that the residual data is normally distributed, no multicollinearity, no autocorrelation, and no heteroscedasticity in the data. Additionally, we also perform bivariate analysis in the form of the Pearson correlation. The result presented in Table 2.

Table 2 Pearson Correlation

\begin{tabular}{|c|c|c|c|c|c|c|c|c|c|c|c|}
\hline & P & EPS & BVS & $O C$ & SIZE & EPSOC & BVSOC & EPSZ & BVSZ & LEPS & ROA \\
\hline EPS & $.719^{* *}$ & & & & & & & & & & \\
\hline BVS & .021 & $.148^{* *}$ & & & & & & & & & \\
\hline OC & $.099^{*}$ & $.089^{*}$ & -.019 & & & & & & & & \\
\hline SIZE & .030 & .000 & $-.246^{* *}$ & $.104^{*}$ & & & & & & & \\
\hline EPSOC & $.655^{* *}$ & $.977^{* *}$ & $.099^{*}$ & $.114^{* *}$ & .011 & & & & & & \\
\hline $\begin{array}{l}\text { BVSO } \\
\text { C }\end{array}$ & .032 & $.164^{* *}$ & $1.000^{* *}$ & -.012 & $-.243^{* *}$ & $.117^{* *}$ & & & & & \\
\hline EPSZ & $.721^{* *}$ & $.995^{* *}$ & .062 & $.096^{*}$ & .034 & $.979^{* *}$ & .079 & & & & \\
\hline BVSZ & $.092^{*}$ & $.237^{* *}$ & $.990^{* *}$ & -.010 & $-.219^{* *}$ & $.179^{* *}$ & $.992^{* *}$ & $.153^{* *}$ & & & \\
\hline LEPS & .000 & $.251^{* *}$ & .008 & $-.106^{* *}$ & .039 & $.271^{* *}$ & .012 & $.243^{* *}$ & .018 & & \\
\hline ROA & $.225^{* *}$ & $.220^{* *}$ & -.004 & .028 & $.124^{* *}$ & $.203^{* *}$ & .000 & $.223^{* *}$ & .019 & .022 & \\
\hline LEV & -.009 & -.020 & -.004 & -.070 & -.002 & -.013 & -.004 & -.020 & -.009 & -.038 & $.711^{* *}$ \\
\hline
\end{tabular}

Specifically, Table 2 presents the multicollinearity test result and proves that the correlation between the independent variable is small (below 0.70 ). It means that there is no multicollinearity. Table 2 also shows that all independent variables correlate in the similar direction as stated in each hypothesis. Although only three of four variables 
which have a significant correlation, namely EPSOC, EPSZ, and BVSZ, these are the initial indication for proving the hypotheses. Therefore, this result will be tested further in the multivariate analysis.

\section{Multivariate Analysis}

Table 3 presents the result of multiple regression analysis for Model 2a, Model 2b, and Model $2 \mathrm{c}$. The result explains that the value of adjusted $\mathrm{R}^{2}$ and $\mathrm{F}$ indicate that all models are significant. Yet, there are distinctions in the explanatory power as is shown by the value of adjusted $R^{2}$. The adjusted $R^{2}$ is $0.086 ; 0.032$; and 0.076 for Model $2 a, 2 b$, and $2 c$ respectively.

Table 3 Regression Analysis

\begin{tabular}{|c|c|c|c|c|c|c|}
\hline \multirow{3}{*}{ Variable } & \multicolumn{2}{|l|}{ Model 2a } & \multicolumn{2}{|l|}{ Model 2b } & \multicolumn{2}{|l|}{ Model 2c } \\
\hline & \multicolumn{2}{|l|}{ Coefficient } & \multicolumn{2}{|l|}{ Coefficient } & \multicolumn{2}{|l|}{ Coefficient } \\
\hline & \multicolumn{2}{|l|}{ (t-statistic) } & \multicolumn{2}{|l|}{ (t-statistic) } & \multicolumn{2}{|l|}{ (t-statistic) } \\
\hline \multirow[t]{2}{*}{ Intercept } & 2.011 & $* * *$ & 2.012 & $* * *$ & 2.011 & $* * *$ \\
\hline & $(2.556)$ & & $(9.736)$ & & (2.197) & \\
\hline \multirow[t]{2}{*}{ EPS } & 0.001 & & -0.002 & $*$ & -0.001 & \\
\hline & $(-1.538)$ & & $(-1.942)$ & & $(-1.066)$ & \\
\hline \multirow[t]{2}{*}{ BVS } & -0.000 & $* *$ & -0.079 & & 0.000 & \\
\hline & $(-2.989)$ & & $(-0.204)$ & & $(1.281)$ & \\
\hline \multirow[t]{2}{*}{$O C$} & 0.026 & $* *$ & & & -0.004 & \\
\hline & $(-2.194)$ & & & & $(-0,251)$ & \\
\hline \multirow[t]{2}{*}{ SIZE } & & & 0.107 & & -0.138 & \\
\hline & & & $(0.295)$ & & $(-1.127)$ & \\
\hline \multirow[t]{2}{*}{ EPSOC } & 0.145 & $* * *$ & & & 0.187 & $* *$ \\
\hline & $(2.607)$ & & & & $(2.153)$ & \\
\hline \multirow[t]{2}{*}{ BVSOC } & 0.000 & $* *$ & & & 0.000 & $* *$ \\
\hline & $(2.341)$ & & & & (2.479) & \\
\hline \multirow[t]{2}{*}{ EPSZ } & & & -0.005 & $* * *$ & -0.005 & $*$ \\
\hline & & & $(-4.248)$ & & $(-1.638)$ & \\
\hline \multirow[t]{2}{*}{ BVSZ } & & & 0.001 & & -0.008 & $* *$ \\
\hline & & & $(0.161)$ & & $(-2.090)$ & \\
\hline \multirow[t]{2}{*}{ LEPS } & 0.016 & $* *$ & 0.001 & $* * *$ & 0.001 & $* *$ \\
\hline & $(2.233)$ & & $(4.656)$ & & $(2.118)$ & \\
\hline \multirow[t]{2}{*}{ ROA } & -0.005 & & 0.002 & & -0.004 & \\
\hline & $(-0.052)$ & & $(0.289)$ & & $(-0.402)$ & \\
\hline \multirow[t]{2}{*}{ LEV } & $-0,289$ & $* *$ & -0.091 & & -0.291 & $* *$ \\
\hline & $(-2,057)$ & & $(-0.296)$ & & $(-1.926)$ & \\
\hline Adj. R2 & 0.086 & & 0.032 & & 0.076 & \\
\hline F-statistics & 8.012 & $* * *$ & 3.056 & $* * *$ & 5.432 & $* * *$ \\
\hline
\end{tabular}

$* * *, * *, *$ show that coeficient is significant at $0.01,0.05$, and 0.1 respectively 
Krismiaji, Wiratno \& Ashari

Ownership Concentration, Firm Size, and Information Value Relevance

To test whether concentration ownership increases the value relevance of financial accounting information (hypothesis 1), the model used is model 2a with the variable of interest are the interaction between EPS and OC (EPSOC) and BVS and OC (BVSOC). The result shows that coefficient of EPSOC is positive $(0.145)$ and significant at the level of $1 \%$, whereas the coefficient of BVSOC is positive (0.000) and significant at the level of $5 \%$. This result indicates that concentration ownership strengthens the value relevance of earnings. Therefore, hypothesis $1 \mathrm{a}$ which stated that concentrated ownership positively affects the value relevance of reported both earnings and book value is supported and confirmed by empirical data. This result confirms some previous research performed by Zhang (2012) which stated that based on the alignment effect, controlling shareholders are willing to build a reputation for not expropriating minority shareholders. Therefore, they motivate management to disclose a high quality of accounting information which contains the value relevance. Moreover, this result is also consistent to the findings of Zeckhauser and Pound (1990) which report that price-toearnings ratio and ownership concentration has a positive relationship and also research performed by Thomsen and Pedersen (2000) who find that after controlling for other variables, ownership concentration has a positive relationship with market-to-book value of equity and return on asset. This result also confirms Bae and Jeong (2007) who report that ownership concentrated firms tend to provide less value-relevant earnings and book value.

To test whether firm size increases the value relevance of financial accounting information (hypothesis 2), the model used is model $2 \mathrm{~b}$ with the variable of interest are the interaction between EPS and Size (EPSZ) and BVS and Size (BVSZ). The result shows that the coefficient of EPSZ is negative $(-0.005)$ and significant at the level of $1 \%$, whereas the coefficient of BVSOC is negative (0.001) and insignificant. This result indicates that firm size decreases the value relevance of earnings, whereas the value relevance of book value is not affected by firm size. Therefore hypothesis 2 which stated that firm size positively affects the value relevance of reported both earnings and book value is not supported and confirmed by empirical data. This result does not confirm prior studies performed by Bae \& Jeong (2007); Brimble and Hodgson (2007) who report that the firm size is a key factor which determines the value relevance of accounting information and Yokoyama, Baioco, Sobrinho, and Neto (2015) who report that large size companies present a more value relevant information than the smaller size companies. Yet, this result confirms and consistent to the result reported by Nilsson and Strand (2015) and Jalalian, Berzegari, and Mohammadi (2016) who find that firm's size has no effect on the value relevance of information. We suspected that the different results are the functions of several factors, such as the number of observations including industries which are used in the research.

\section{Robustness Test.}

To test whether the regression result from Model $2 \mathrm{a}$ and Model $2 \mathrm{~b}$ are robust, we use Model 2c. The result shows in Table 3. The result of Model $2 a$ which tests hypotheses 1 
is consistent with that of Model 2c. Additionally, the result of Model $2 b$ which tests hypotheses 2 is consistent for the value relevance of reported earnings but is not consistent with the book value. It means that concentration ownership positively affects both earnings per share and book value per share. Therefore both the result of Model $2 \mathrm{a}$ and Model $2 \mathrm{c}$ informs that hypothesis 1 confirmed by empirical data. Model 2 reports that firm size negatively affects both reported earnings per share and book value per share. The result of Model $2 b$ and Model $2 c$ indicate that firm size does not positively affect the value relevance of both earnings per share and book value per share. Therefore hypothesis 2 which stated that firm size positively affects the value relevance of accounting information is not supported by empirical observation. It can be concluded that the result is robust.

\section{Conclusion}

This research investigates the effect of concentration ownership and firm size on the value relevance of accounting information. The result shows that hypothesis 1 which stated that concentration ownership positively affects the value relevance of accounting information is received and supported by empirical data, whereas hypothesis 2 which stated that firm size positively affects the value relevance of accounting information is rejected and itis not supported by empirical data.

This research has two limitations so that it opens an opportunity for further research in the future. First, this research uses five years of data. If this period is related to concentrated ownership and firm size tend to be unchanged for five years. Therefore, future research can be performed by involving other dynamic variables which theoretically affect the value relevance of accounting information. Second, this research uses manufacturing companies as the only observation data. This study leads to the result could not be broadly generalized. Therefore, future research needs to be performed by involving other industries which may produce different result as the consequence of different industry characteristics.

\section{References}

Alfraih, M.M., FS. Alanezi, \& K.A. Alanzi. (2015). Do the characteristics of the board of directors affect the value relevance of accounting information? International Journal of Accounting and Finance, 5(2), 172-187. https://doi.org/10.1504/IJAF.2015.071843

Anderson, R. C., Mansi, S. A., \& Reeb, D. M. (2003). Founding family ownership and the agency cost of debt. Journal of Financial Economics, 68(2), 263-285. https://doi.org/10.1016/S0304-405X(03)00067-9

Bae, K.H., \& Jeong, S.W. (2007). The value-relevance of earnings and book value, ownership structure, and business group affiliation: Evidence from Korean Business Groups. Journal of Business Finance \& Accounting, 34(5), 740-766. https://doi.org/10.1111/j.1468-5957.2007.02017.x

Ball, R., \& Brown, P. (1968). An empirical evaluation of accounting income numbers. Journal of Accounting Research, 6(2): 159-178. https://doi.org/10.2307/2490232 
Barnea, A, R. A. Haugen, \& L. W. Senbet. (1985). Agency Problems and Financial Contracting. New Jersey: Prentice Hall, Inc.

Barth, M.E., Beaver, W.H., \& Landsman, W.R. (1998). Relative valuation roles of equity book value and net income as a function of financial health. Journal of Accounting and Economics, 25(1), 1-34. https://doi.org/10.1016/S0165-4101(98)00017-2

Beaver, W.H. (2002): Perspectives on recent capital market research, Accounting Review, 77(2), 453-474. https://doi.org/10.2308/accr.2002.77.2.453

Brimble, M., \& Hodgson, A. (2007). On the inter-temporal value relevance of conventional financial accounting in Australia. Accounting and Finance, 47(4), 599-622. https://doi.org/10.1111/j.1467-629X.2007.00241.x

Chen, W. \& W. Huang. 2014. A replication study of Ball \& Brown (1968): Comparative analysis of China and the US, China Accounting and Finance Review, 16(2), 66-89. https://doi.org/10.7603/s40570-014-0007-1

Chen, P., \& Zhang, G. (2007). How do accounting variables explain stock price movements? Theory and evidence. Journal of Accounting and Economics, 43(2-3), 219-244. https://doi.org/10.1016/i.jacceco.2007.01.001

Collins, D. W., E. L. Maydew, \& I.S. Weiss. (1997). Changes in the value-relevance of earnings and book values over the past forty years. Journal of Accounting \& Economics, 24(1), 39-67. https://doi.org/10.1016/S0165-4101(97)00015-3

Collins, D. W., M. Pincus, \& H. Xie. (1999). Equity valuation and negative earnings: The role of the book value of equity. The Accounting Review, 74(1), 2961. https://doi.org/10.2308/accr.1999.74.1.29

Demsetz, H., \& Lehn, K. (1985). The structure of corporate ownership: Causes and consequences. The Journal of Political Economy, 93(6), 1155. http://dx.doi.org/10.1086/261354

Fama, E. F., \& Jensen, M. C. (1983). Separation of ownership and control. Journal of Law and Economics, 26(2): 301-325. http://dx.doi.org/10.2139/ssrn.94034

Francis, J., \& Schipper, K. (1999). Have financial statements lost their relevance? Journal of Accounting Research, 37(2), 319-352. https://doi.org/10.2307/2491412

Gomes, A. (2000). Going public without governance: Managerial reputation effects. The Journal of Finance, 55(2), 615-646. https://doi.org/10.1111/0022-1082.00221

Harris, T.S. \& J.A. Ohlson. (1990). Accounting disclosures and the market's valuation of oil and gas properties: Evaluation of market efficiency and functional fixation. The Accounting Review, 65(4), 764-780

Hasso, T., \& Duncan, K. (2013). Valuation of Family Firms: The Limitations of Accounting Information. Australian Accounting Review: ISSN 1035-6908.

Hasso, T. (2013). Family ownership and value relevance of accounting information. Dissertation, School of Business, Bond University, Australia

Healy, P.M., \& K.G. Palepu. (2001). Information asymmetry, corporate disclosure, and the capital markets: A review of the empirical disclosure literature, Journal of Accounting and Economics, 31, 404-440. https://doi.org/10.1016/S0165-4101(01)00018-0

Hodgson, A., \& Clarke, S.P. (2000). Earnings, cash flow and returns: functional relations and the impact of firm size. Accounting and Finance, 40(1), 51-73. https://doi.org/10.1111/1467-629X.00035

Holthausen, R., \& Watts R (2001). The relevance of the value relevance literature for financial accounting standard setters, Journal of Accounting and Economics, 31, 3-75. http://dx.doi.org/10.2139/ssrn.246861

Jalalian, T., J. Berzegari, \& H.R. Mohammadi. (2016). Investigating the effect of firm size and financial leverage on the relationship between cost management and relevance of accounting information, The Caspian Sea Journal, 10(1), Supplement 4, 335-342 
Jensen, M. \& W. Meckling. (1976). Theory of the firm: managerial behavior, agency costs, and ownership structure. Joumal of Financial Economics, 3(3), 305-360. https://doi.org/10.1016/0304-405X(76)90026-X

Kim, J.B., \& H. Shi. (2012). IFRS reporting, firm-specific information flows, and institutional environments: international evidence. Review of Accounting Studies, 17(3), 474 - 517. DOI: $10.1007 / \mathrm{s} 11142-012-9190-\mathrm{y}$

Krismiaji. (2013). International Financial Reporting Standards, corporate governance, dan kualitas informasi akuntansi. Doctoral Dissertation, Universitas Negeri Sebelas Maret, Indonesia.

Krismiaji, Y A. Aryani, \& D. Suhardjanto. (2016). International Financial Reporting Standards, board governance, and accounting quality - A preliminary Indonesian evidence. Asian Review of Accounting, 24(4), 474 - 497. https://doi.org/10.1108/ARA-06-2014-0064

Krismiaji \& Hermala K. D. (2018). Boards' characteristics, voluntary disclosure, and accounting information value relevance - Indonesian Evidence. Working paper, Akademi Akuntansi YKPN.

Larcker, D. F., \& Richardson, S. A. (2004). Fees paid to audit firms, accrual choices, and corporate governance. Journal of Accounting Research, 42(3), 625-656. https://doi.org/10.1111/j.1475-679X.2004.t01-1-00143.x

Leng, A.A.C. (2004). The impact of corporate governance practices on firms financial performance: Evidence from Malaysian companies. SEAN Economic Bulletin, 21(3), 308-318. https://doi.org/10.1353/ase.2011.0056

Leuz, C., D. Nanda, \& P. Wysocki. (2003). Earnings management and investor protection: An international comparison, Joumal of Financial Economics, 69(3), 505-527. https://doi.org/10.1016/S0304-405X(03)00121-1

Miller, D., Le Breton-Miller, I., Scholnick, B., \& Montreal, H. (2008). Stewardship vs. stagnation: An empirical comparison of small family and non-family businesses. Journal of Management Studies, 45(1), 51-78. https://doi.org/10.1111/j.14676486.2007.00718.x

Nilsson, J., \& H. Strand. (2015). The impact of company size on the value relevance of social ratings, $A$ quantitative study. Thesis, the Umeå School of Business and Economics, Umeå University

Ohlson, A.J. (1995). Earnings, book values, and dividends in security valuation. Contemporary Accounting Research, 11(2), 661-687. https://doi.org/10.1111/i.1911$\underline{3846.1995 . t b 00461 . x}$

Pathirawasam, C. (2013). The value relevance of earnings and book value: The importance of ownership concentration and firm size. Journal of Competitiveness, 5(2), 98-107. https://doi.org/10.7441/joc.2013.02.07

Pathirawasam, C. (2010). Value relevance of accounting information: evidence from Sri Lanka. International Journal of Research in Commerce \& Management, 8(1), 13-20.

Ronen, J., \& Yaari, V. L. (2002). Incentives for voluntary disclosure. Journal of Financial Markets, 5(3), 349-390. https://doi.org/10.1016/S1386-4181(01)00034-9

Shleifer, A., \& Vishny, R. W. (1997). A survey of corporate governance. The Journal of Finance, 52(2), 737-783. https://doi.org/10.1111/i.1540-6261.1997.tb04820.x

Sirmon, D. G., \& Hitt, M. A. (2003). Managing resources: linking unique resources, management, and wealth creation in family firms. Entrepreneurship: Theory and Practice, 27(4): 339-359. https://doi.org/10.1111/1540-8520.t01-1-00013

Tariverdi, Y., L. Sedighikamal, \& S. Naderi. (2016). The effect of ownership structure on the value relevance of accounting information: An Empirical Evidence from Iran, International Journal of Recent Scientific Research, 7(5), 10980-10987. 
Thomsen, S., \& Pedersen, T. (2000). Ownership structure and value of the largest European firms: The importance of owner identity. Strategic Management Journal, 21(6), 689-705. https://doi.org/10.1023/A:1022480016567

Villalonga, B., \& Amit, R. (2006). How do family ownership, control, and management affect firm value? Journal of Financial Economics, 80, 385-417. https://doi.org/10.1016/j.jfineco.2004.12.005

Zeckhauser, R. J., \& Pound, J. (1990). In Hubbard, R. G (Ed.), are large shareholders effective monitors? An investigation of share ownership and corporate performance (pp. 149-180). University of Chicago Press.

Zhang. M. (2012). Board structure, ownership concentration, and intellectual capital. Dissertation, Victoria University of Wellington, Australia.

Zhou, J. \& Lobo, G. J. 2006. Did conservatism in financial reporting increase after the Sarbanes-Oxley Act? Initial evidence. Accounting Horizons, 20(1), 57-73. https://doi.org/10.2308/acch.2006.20.1.57 